Tomasz Kaczmarek ${ }^{1}$, Magdalena Szmytkowska ${ }^{2}$

\author{
${ }^{1}$ Uniwersytet im. Adama Mickiewicza $w$ Poznaniu \\ Wydziat Geografii Społeczno-Ekonomicznej i Gospodarki Przestrzennej \\ tomkac@amu.edu.pl \\ ${ }^{2}$ Uniwersytet Gdański \\ Wydziat Oceanografii i Geografii \\ geoms@univ.gda.pl
}

\title{
Problematyka miejskich obszarów funkcjonalnych (metropolitalnych) w badaniach polskich geografów społeczno-ekonomicznych
}

\begin{abstract}
Zarys treści: Od niemal dwudziestu lat w Polsce trwa intensywny polityczny i naukowy dyskurs metropolitalny, związany z problematyką rozwoju wielkomiejskimi struktur osadniczych i ich zarządzania. Kwestie te stały się także przedmiotem badań przedstawicieli geografii społeczno-ekonomicznej. Celem opracowania jest wykazanie dorobku polskich geografów na temat obszarów metropolitalnych (miejskich obszarów funkcjonalnych). Przyjęto dwie zasadnicze metody badawcze: przegląd prac geograficznych opublikowanych w latach 2000-2017 oraz ankietę na temat aktywności eksperckiej geografów działających w 11 głównych ośrodkach geograficznych w Polsce. Wykazano znaczący dorobek geografów, dotyczący zagadnień rozwoju miejskich obszarów funkcjonalnych i metropolitalnych. W podsumowaniu przedstawiono rekomendacje w zakresie dalszych badań metropolitalnych w polskiej geografii społeczno-ekonomicznej.
\end{abstract}

Słowa kluczowe: obszary metropolitalne, miejskie obszary funkcjonalne, zarządzanie terytorialne, dorobek badań geograficznych

\section{Wprowadzenie}

Od niemal dwudziestu lat w Polsce trwa intensywny dyskurs metropolitalny, zarówno naukowy, jak i polityczny, dotyczący problemów rozwoju i zarządzania wielkomiejskich struktur osadniczych, jakimi są obszary metropolitalne. W ostatnich latach kwestia współpracy międzygminnej jest również związana z mniejszymi ośrodkami miejskimi oraz ich obszarami funkcjonalnymi, tworzącymi pewne struktury funkcjonalno-przestrzenne wykraczające poza istniejące struktury administracyjne, wymagające kompleksowych i zintegrowanych ujęć, 
zarówno w kontekście badań naukowych, jak i praktyki zarządzania oraz planowania przestrzennego.

Problematyka metropolitalna $z$ jednej strony jest związana $z$ dynamicznym rozwojem społeczno-gospodarczym największych polskich miast, w których zaczęły wykształcać się funkcje i powiązania metropolitalne (m.in. Zuzańska-Żyśko 2016), natomiast $z$ drugiej $-z$ ich rozwojem przestrzennym, wykraczającym poza granice administracyjne na skutek żywiołowych procesów suburbanizacyjnych (urban sprawl), wynikających $\mathrm{w}$ głównej mierze $\mathrm{z}$ neoliberalnych reguł zarządzania przestrzenią. Procesy metropolizacji i suburbanizacji doprowadziły na wielu obszarach do chaotycznego kształtowania się nowych struktur funkcjonalno-przestrzennych, złożonych z miasta centralnego i jego szeroko pojętej strefy podmiejskiej, administracyjnie podlegającej innym jednostkom terytorialnym.

Wobec tego stanu rzeczy, ponad dziesięć lat temu rozpoczęły się publiczne debaty nad wprowadzeniem rozwiązań ustrojowych, które sankcjonowałyby wyodrębnienie obszarów metropolitalnych w systemie administracji samorządowej (Kaczmarek 2018, s. 282). Zasadniczymi problemami występującymi w dyskursie metropolitalnym były: delimitacja oraz prawne uregulowanie statusu obszarów metropolitalnych (i miejskich obszarów funkcjonalnych). Kwestia delimitacyjna wiązała się ze wskazaniem optymalnych kryteriów, według których można by wyznaczyć obszar metropolitalny (funkcjonalny), agregowanych zazwyczaj do dwóch kategorii (Szmytkowska 2014, s. 26):

- statystyczno-geograficznej (wyznaczenie grupy wskaźników o charakterze ilościowym, będących podstawą określenia potencjału metropolitalnego),

- funkcjonalnej (wskazanie powiązań funkcjonalno-przestrzennych oraz funkcji miejskich o znaczeniu ponadregionalnym i międzynarodowym).

Z kolei kwestia prawna dotyczyła dwóch grup dylematów związanych z procesem ustanowienia obszaru metropolii:

1. odgórnego (top-down) versus oddolnego (bottom up) kształtowania struktur metropolitalnych,

2. obligatoryjnej versus dobrowolnej przynależności jednostek samorządu terytorialnego do obszaru metropolitalnego.

Kluczowym wątkiem w prowadzonym dyskursie metropolitalnym, a później także związanym $z$ kształtowaniem miejskich obszarów funkcjonalnych, była ich delimitacja. Konieczność wyznaczenia MOF-ów była podstawowym warunkiem zawiązania partnerstwa i opracowania strategii ZIT, co gwarantowało możliwość pozyskania środków unijnych (Kociuba 2017). Rządową decyzję o opracowaniu delimitacji MOF OW podjęto w 2012 r. i zadanie to powierzono prof. Przemysławowi Śleszyńskiemu (2013?). Przyjęta delimitacja została oparta na definicji obszaru funkcjonalnego ośrodka wojewódzkiego jako spójnej pod względem przestrzennym strefy oddziaływania miasta, charakteryzującej się istnieniem powiązań funkcjonalnych oraz zaawansowanych procesów urbanizacyjnych, wyróżniającej się z otoczenia i upodabniającej się pod pewnymi względami do głównego miasta (Śleszyński 2013).

Brak konsensusu politycznego związanego $z$ prawnym uregulowaniem statusu miejskich obszarów funkcjonalnych (metropolitalnych) i niepowodzenia 
odgórnego ich stanowienia sprawiły, że do czasu podjęcia inicjatywy w postaci Zintegrowanych Inwestycji Terytorialnych (ZIT) polityka rządu sprowadzała się do finansowego wspierania oddolnych form integracji miast i ich otoczenia (Kaczmarek 2017, s. 160). Założenia polityki Unii Europejskiej na nowy okres finansowania 2014-2020 dotyczące polityki miejskiej zakładały wzmocnienie współpracy na osi miasto-otoczenie poprzez wprowadzenie Zintegrowanych Inwestycji Terytorialnych, realizowanych w ramach tzw. miejskich obszarów funkcjonalnych (MOF). W Polsce reakcją na promiejską politykę unijną było sformułowanie przez Ministerstwo Infrastruktury i Rozwoju projektu Krajowej Polityki Miejskiej (KPM), której założeniem było określenie działań państwa na rzecz zrównoważonego rozwoju miast i ich obszarów funkcjonalnych oraz wykorzystanie ich potencjałów w procesach rozwoju kraju (Frankowski, Szmytkowska 2015, s. 136). Pomimo zdecydowanie dłużej trwającego dyskursu metropolitalnego, dopiero inicjatywa Unii Europejskiej dotycząca wsparcia finansowego projektów w miejskich obszarach funkcjonalnych wyraźnie zaktywizowała samorządy do podjęcia bądź pogłębienia współpracy metropolitalnej i za sprawą instrumentu ZIT podziałała również mobilizująco na rząd polski (Krukowska, Lackowska 2016, s. 102).

Miejskie obszary funkcjonalne miały być zatem przede wszystkim tak wyznaczonymi jednostkami planistycznymi, by w sposób efektywny przeciwdziałać wspólnym problemom miast i ich otoczenia (Bartosiewicz 2016, s. 40). Zdefiniowanie takich obszarów miało kluczowe znaczenie w polityce rozwoju, ponieważ pojęcia, na których opierała się dotychczas polityka rozwoju miast i gmin, zamykały się w obrębie granic administracyjnych i z reguły nie odpowiadały rzeczywistym układom przestrzennym (Heffner, Gibas 2015, s. 11). Koncepcja ZIT okazała się interesująca nie tylko jako nowość w realizowanej w Polsce polityce spójności, ale jako realna możliwość wdrażania i rozszerzania na kolejne obszary zintegrowanego podejścia w zarządzaniu lokalnym (Kozak 2016, s. 62).

Wyżej wymienione kwestie rozwoju miejskich (metropolitalnych) obszarów funkcjonalnych, ich zagospodarowania oraz zarządzania nimi stały się w Polsce obiektem wzmożonych badań przedstawicieli różnych dyscyplin, w szczególności geografii społeczno-ekonomicznej i gospodarki przestrzennej, urbanistyki, socjologii, politologii i nauk prawno-administracyjnych. Celem opracowania jest wykazanie roli polskich geografów społeczno-ekonomicznych, w szczególności osadnictwa i ludności, jaką odegrali w dyskursie na temat obszarów metropolitalnych i miejskich obszarów funkcjonalnych.

\section{Cele i metody badań}

Zasadniczym celem opracowania jest uzyskanie odpowiedzi na następujące pytania:

1. Jaki jest dorobek geografii w zakresie badań miejskich obszarów funkcjonalnych (metropolitalnych) i co jest przedmiotem tych badań?

2. W jakim zakresie znajdują one zastosowanie $\mathrm{w}$ praktyce?

3. Czy geografowie uczestniczą w gremiach politycznych i eksperckich mających realny wpływ na funkcjonowanie i rozwój miejskich obszarów funkcjonalnych? 
4. Jakie są wyzwania i kierunki dalszych badań?

W toku realizacji opracowania przyjęto dwie zasadnicze metody badawcze. Bazę do analiz ilościowych dorobku naukowego tworzył wykaz prac geograficznych opublikowanych w latach 2000-2017. Szczególnie pomocna okazała się publikacja przygotowana przez członków Komisji Geografii Osadnictwa i Ludności Polskiego Towarzystwa Geograficznego (KGOiL PTG) i zredagowana przez D. Sokołowskiego pt.: „Bibliografia prac z zakresu geografii osadnictwa i ludności za lata 1999-2015". Poza szczegółowym przeglądem literatury, opracowano również ankietę na temat aktywności badawczej i eksperckiej geografów związanej $z$ istnieniem obszarów metropolitalnych i funkcjonalnych, którą rozesłano do wszystkich ośrodków geograficznych w Polsce i której realizacja była nadzorowana przez członków KGOiL PTG, wywodzących się z poszczególnych ośrodków. Ostatecznie uzyskano odpowiedzi z następujących ośrodków badawczych ${ }^{1}$ :

1. Centrum Europejskich Studiów Regionalnych EUROREG w Warszawie,

2. Instytut Geografii i Przestrzennego Zagospodarowania PAN w Warszawie,

3. Uniwersytet Gdański,

4. Uniwersytet im. Adama Mickiewicza w Poznaniu,

5. Uniwersytet im. Marii Curie-Skłodowskiej w Lublinie,

6. Uniwersytet Jagielloński w Krakowie,

7. Uniwersytet Łódzki,

8. Uniwersytet Szczeciński,

9. Uniwersytet Śląski,

10. Uniwersytet Warszawski,

11. Uniwersytet Wrocławski.

Analizie poddano następujące formy zaangażowania geografów $\mathrm{w}$ dyskurs dotyczący miejskich obszarów funkcjonalnych i obszarów metropolitalnych:

- publikacje z wyszczególnieniem problemów badawczych,

- projekty badawcze,

- udział w opracowaniach strategicznych i planistycznych,

- udział w gremiach eksperckich i doradczych,

- zaangażowanie w debatę publiczną,

- organizację konferencji poświęconych MOF i OM.

Analiza dorobku ma głównie charakter ilościowy. Dla uporządkowania zebranego materiału wyróżniono jednak dwie zasadnicze grupy badań, w których uczestniczyli geografowie, czyli badania podstawowe, do których zaliczono oryginalne prace badawcze teoretyczne i empiryczne podejmowane w celu zdobywania nowej wiedzy o zjawiskach i procesach obserwowalnych w miejskich (metropolitalnych) obszarach funkcjonalnych, oraz badania stosowane, za które przyjęto prace badawcze podejmowane i zorientowane przede wszystkim na zastosowanie w praktyce, wykorzystywane $\mathrm{w}$ formułowaniu i realizacji polityk publicznych, programowaniu rozwoju, zarządzaniu strategicznym i planowaniu przestrzennym. W tabeli 1

Autorzy składają serdeczne podziękowania wszystkim przedstawicielom ww. Komisji PTG oraz ośrodkom naukowym za zaangażowanie w sporządzenie wykazu literatury i udział w ankiecie badawczej. 
Tabela 1. Problematyka badań geograficznych dotyczących miejskich obszarów funkcjonalnych i obszarów metropolitalnych

\begin{tabular}{|c|c|c|}
\hline $\begin{array}{l}\text { Kategoria } \\
\text { badań }\end{array}$ & Grupy badań & Problematyka badań \\
\hline \multirow{6}{*}{ 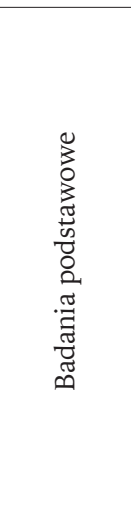 } & Prace teoretyczne & $\begin{array}{l}\text { - kwestie terminologiczne } \\
\text { - system osadniczy } \\
\text { - klasyfikacje i hierarchizacje } \\
\text { - procesy rozwojowe }\end{array}$ \\
\hline & Prace metodologiczne & $\begin{array}{l}\text { - metody badań struktur i powiązań } \\
\text { - kryteria i metody delimitacji }\end{array}$ \\
\hline & Badania funkcji & $\begin{array}{l}\text { - analiza funkcji (w tym metropolitalnych) } \\
\text { - ekspansja funkcji na obszar funkcjonalny }\end{array}$ \\
\hline & Badania struktur i powiązań & $\begin{array}{l}\text { - struktury przestrzenno-funkcjonalne } \\
\text { - określanie skali i kierunków powiązań }\end{array}$ \\
\hline & Integracja zarządzania & $\begin{array}{l}\text { - modele zarządzania } \\
\text { - badania istniejących struktur zarządzania }\end{array}$ \\
\hline & Badania kompleksowe & $\begin{array}{l}\text { - diagnozy funkcjonowania MOF (OM) } \\
\text { - projekcje i prognozy rozwoju MOF (OM) }\end{array}$ \\
\hline \multirow{6}{*}{ 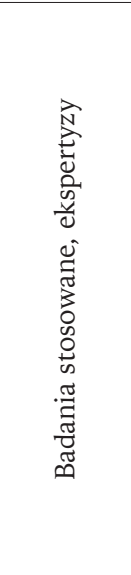 } & $\begin{array}{l}\text { Ekspertyzy dla instytucji } \\
\text { międzynarodowych }\end{array}$ & $\begin{array}{l}\text { - polityki miejskie wobec OM (OECD, ESPON) } \\
\text { - polityki regionalne (UE-ZIT) }\end{array}$ \\
\hline & Prace na poziomie krajowym & $\begin{array}{l}\text { - prace na użytek koncepcji i dokumentów programo- } \\
\text { wych (np. KPZK) } \\
\text { - prace na potrzeby polityk branżowych (np. Krajowa } \\
\text { Polityka Miejska) }\end{array}$ \\
\hline & $\begin{array}{l}\text { Prace na poziomie regional- } \\
\text { nym }\end{array}$ & - polityki i plany regionalne względem MOF (OM) \\
\hline & Programowanie rozwoju & $\begin{array}{l}\text { - strategie rozwoju MOF }(\mathrm{OM}) \\
\text { - plany (studia) rozwoju przestrzennego } \\
\text { - masterplany itp }\end{array}$ \\
\hline & Tworzenie baz danych & $\begin{array}{l}\text { - bank danych statystycznych dla MOF (OM) } \\
\text { - bazy danych przestrzennych, np. SIP dla MOF (OM) }\end{array}$ \\
\hline & Monitoring i ewaluacja & $\begin{array}{l}\text { - monitoring przebiegu i rezultatów działań w MOF } \\
(\mathrm{OM}) \\
\text { - oceny, postulaty i rekomendacje do polityk }\end{array}$ \\
\hline
\end{tabular}

Źródło: opracowanie własne.

dokonano wyszczególnienia obu omówionych powyżej kategorii badań, na bazie którego dokonano oceny dorobku i wkładu geografów w badania MOF i OM.

Choć autorzy mają świadomość, że zebrany materiał informacyjny nie jest kompletny, to z pewnością jego analizy pozwoliły na określenie wkładu polskich geografów miast w badania teoretyczne i aplikacyjne dotyczące miejskich obszarów funkcjonalnych i obszarów metropolitalnych ${ }^{2}$.

2 Wyniki prezentowanych w artykule badań autorzy referowali na Kongresie Geografii Polskiej z okazji 100-lecia Polskiego Towarzystwa Geograficznego, który odbył się w 12 kwietnia 2018 r. na Uniwersytecie Warszawskim. 


\section{Dorobek polskich geografów w zakresie badań nad miejskimi obszarami funkcjonalnymi i metropolitalnymi}

Polscy geografowie $\mathrm{w}$ znaczącym stopniu partycypują $\mathrm{w}$ badaniach miejskich obszarów funkcjonalnych oraz obszarów metropolitalnych, uczestnicząc aktywnie $\mathrm{w}$ prowadzonym w Polsce dyskursie na każdym jego etapie, nie tylko jako naukowcy, ale również eksperci i praktycy. Przeprowadzona na potrzeby opracowania inwentaryzacja dorobku naukowo-badawczego jest potwierdzeniem zaangażowania geografów i znaczenia realizowanych prac zarówno w jego teoretycznym, jak i aplikacyjnym wymiarze.

Analizie poddano łącznie 226 prac naukowych klasyfikowanych do badań podstawowych, pośród których $23 \%$ stanowiły prace teoretyczno-metodologiczne, a pozostałe $77 \%$ - prace empiryczne. W strukturze prac naukowych według czasu ich opublikowania zauważa się systematyczny wzrost liczby opracowań geograficznych, zarówno teoretyczno-metodologicznych, jak i empirycznych, co bezsprzecznie wynika z zaistnienia kwestii obszarów metropolitalnych i miejskich obszarów funkcjonalnych w dyskursie publicznym (ryc. 1).

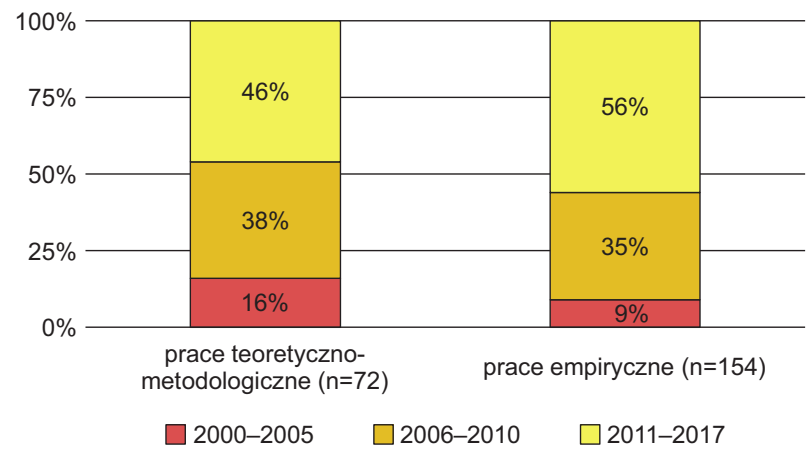

Ryc. 1. Struktura geograficznych prac naukowych według okresu publikacji Źródło: opracowanie własne.

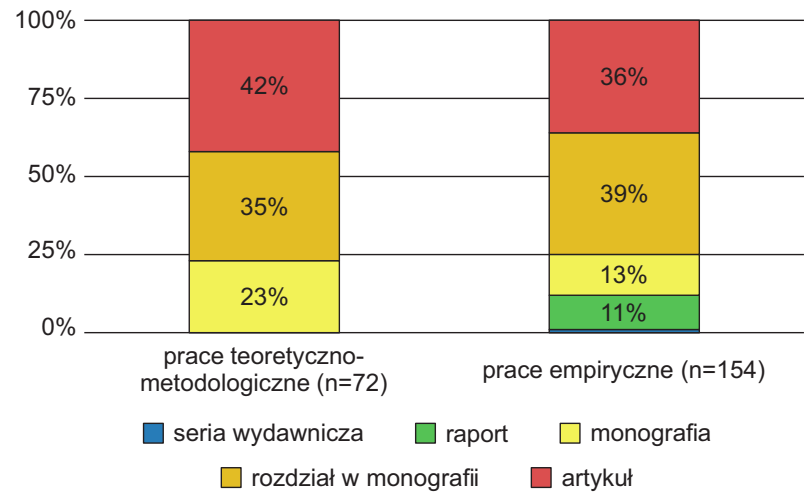

Ryc. 2. Struktura geograficznych prac naukowych według rodzaju publikacji $(n=226)$ Źródło: opracowanie własne. 
W strukturze publikacji według rodzajów dominują artykuły naukowe oraz rozdziały w monografiach, które łącznie obejmują 75\% dorobku geografów. Około $16 \%$ ogółu stanowią monografie, przy czym ich udział w pracach teoretyczno-metodologicznych wynosi niemal $25 \%$ ogółu opracowań, natomiast w pracach empirycznych około $13 \%$, co wynika z charakteru tego typu publikacji. Badania empiryczne geografów publikowane są ponadto w formie raportów (11\%) oraz serii wydawniczej, publikowanej cyklicznie przez UAM w Poznaniu (ryc. 2).

Prace geografów dotyczą całego spektrum problematyki związanej z miejskimi obszarami funkcjonalnymi i obszarami metropolitalnymi. Z przeglądu zebranego materiału publikacyjnego wynika, że w ramach badań podstawowych zrealizowano badania podejmujące zagadnienia z zakresu:

- teorii i modelowania,

- delimitacji,

- struktur,

- funkcji,

- powiązań,

- zarządzania.

$\mathrm{Na}$ rycinie 3 przedstawiono strukturę opracowań geograficznych według problematyki z zachowaniem podziału na prace teoretyczno-metodologiczne i empiryczne.

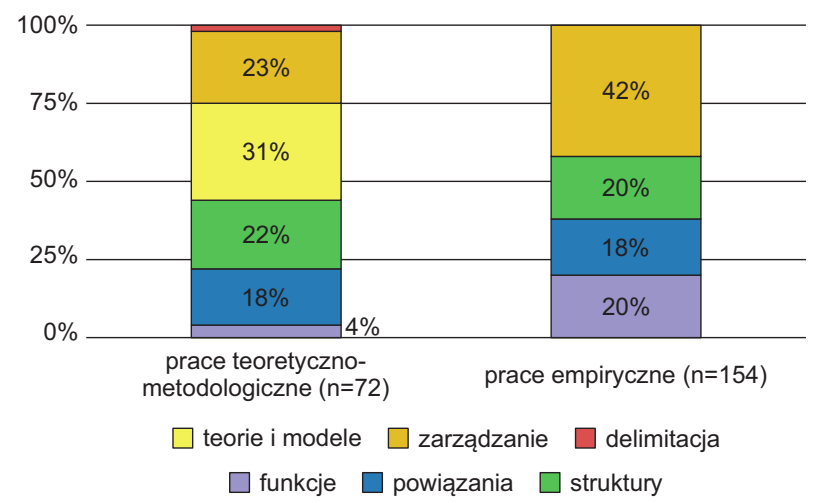

Ryc. 3. Struktura geograficznych prac naukowych według problematyki $(n=226)$

Źródło: opracowanie własne.

Co zrozumiałe, najwyższy udział w pracach teoretyczno-metodologicznych mają prace $z$ zakresu teorii i modelowania obszarów funkcjonalnych i metropolitalnych (31\%). Z kolei w przypadku prac empirycznych ważną problematyką są funkcje MOF i OM, podjęte w $20 \%$ prac (przy zaledwie $2 \%$ prac teoretyczno-metodologicznych). W obu kategoriach prac bardzo ważną tematyką badawczą jest zarządzanie MOF i OM: w opracowaniach teoretycznych stanowi ona 23\%, a w empirycznych - aż 42\%. Kolejnymi grupami zagadnień tematycznych najczęściej podejmowanymi w pracach geograficznych są struktury przestrzenno-funkcjonalne (odpowiednio 22\% i 20\%) oraz powiązania w ramach obszarów funkcjonalnych (metropolitalnych) (po 18\%). 
Wyrazem zainteresowania geografów problematyką miejskich obszarów funkcjonalnych i obszarów metropolitalnych jest organizacja konferencji naukowych. W latach 2002-2018 zrealizowano 27 tego typu wydarzeń, przy czym szczególne natężenie miało miejsce w latach 2015-2017, czyli w okresie wdrażania instrumentu Zintegrowanych Inwestycji Terytorialnych dla miejskich obszarów funkcjonalnych, głównie miast wojewódzkich.

Jak wspomniano, Polscy geografowie angażują się również w badania stosowane, mające walor aplikacyjny. $Z$ powodu trudności związanych z ilościowym ujęciem tego typu aktywności, określono jedynie obszary życia publicznego, w których wiedza i doświadczenie geografów są wykorzystywane. Podstawą tej klasyfikacji są wskazania i deklaracje pracowników naukowych z ośrodków akademickich odnośnie do angażowania się w poszczególne typy działalności (tab. 2).

Tabela 2. Zaangażowanie polskich geografów $\mathrm{w}$ badania o charakterze aplikacyjnym oraz aktywność w życiu publicznym na rzecz kształtowania MOF i OM

\begin{tabular}{|c|c|c|}
\hline $\begin{array}{c}\text { Współpraca ekspercka } \\
\text { i naukowa }\end{array}$ & $\begin{array}{c}\text { Współpraca z rządowymi } \\
\text { i samorządowymi instytucjami lokalnymi } \\
\text { i regionalnymi }\end{array}$ & $\begin{array}{l}\text { Współpraca z instytu- } \\
\text { cjami komercyjnymi }\end{array}$ \\
\hline $\begin{array}{l}\text { - sieci naukowe } \\
\text { - międzynarodowe } \\
\text { i krajowe konsorcja } \\
\text { naukowe } \\
\text { - think-tanki } \\
\text { - fundacje }\end{array}$ & $\begin{array}{l}\text { - udział w programowaniu rozwoju MOF i OM } \\
\text { (planowanie strategiczne, przestrzenne i zinte- } \\
\text { growane, delimitacje MOF) } \\
\text { - udział w debacie nad politykami publicznymi, } \\
\text { w tym przestrzennymi } \\
\text { - głos geografów w kwestiach zarządzania teryto- } \\
\text { rialnego i tworzenia prawa } \\
\text { - udział w gremiach politycznych, zarządczych } \\
\text { w charakterze ekspertów, doradców i członków. }\end{array}$ & $\begin{array}{l}\text { - działalność konsul- } \\
\text { tingowa } \\
\text { i ekspercka }\end{array}$ \\
\hline
\end{tabular}

Źródło: opracowanie własne.

Tabela 3. Udział geografów w wybranych opracowaniach strategicznych dotyczących MOF i OM

\begin{tabular}{cl}
\hline $\begin{array}{c}\text { Rok } \\
\text { opracowania }\end{array}$ & \multicolumn{1}{c}{ Tytuł dokumentu } \\
\hline 2010 & Strategia rozwoju Górnośląsko-Zagłębiowskiej Metropolii Silesia do 2025 r. \\
2010 & Strategia rozwoju aglomeracji poznańskiej. Metropolia Poznań 2020 \\
2013 & Główne kierunki i wyzwania rozwojowe aglomeracji Trójmiasta \\
2013 & Koncepcja zrównoważonej polityki miejskiej województwa pomorskiego \\
2014 & Strategia rozwoju Miejskiego Obszaru Funkcjonalnego Lęborka \\
2014 & Założenia strategii zintegrowanych inwestycji terytorialnych MOF BTOM \\
2014 & Strategia Mieleckiego Obszaru Funkcjonalnego \\
2014 & Program rozwoju gospodarczego Metropolii Silesia do 2025 r. \\
2015 & Założenia strategii zintegrowanych inwestycji terytorialnych MOF Warszawy \\
2015 & Strategia rozwoju Gdańskiego Obszaru Metropolitalnego do 2030 r. \\
2015 & Strategia zintegrowanych inwestycji terytorialnych MOF Poznania \\
2016 & Strategia Miejskiego Obszaru Funkcjonalnego Olsztyna w zakresie ZIT \\
2016 & Strategia rozwoju Elbląskiego Obszaru Funkcjonalnego \\
2017 & Koncepcja kierunków rozwoju przestrzennego Metropolii Poznań \\
\hline
\end{tabular}

Źródło: opracowanie własne. 
W szczególny sposób zaznacza się udział geografów w pracach nad dokumentami planistycznymi i strategicznymi, dotyczącymi miejskich obszarów funkcjonalnych i metropolitalnych. W tabeli 3 zestawiono wybrane opracowania strategiczne, w których geografowie byli kluczowymi członkami zespołów autorskich.

Istotny w kontekście zaangażowania w realizację opracowań lokalnych i regionalnych jest także fakt aktywnego udziału w pracach nad realizacją tego typu dokumentów absolwentów kierunków geograficznych, którzy znajdują zatrudnienie w instytucjach samorządowych i częstokroć - za sprawą wykształcenia i kompetencji - są angażowani do opracowań diagnostycznych i strategicznych.

\section{Wnioski}

Przedstawiona w artykule analiza dorobku polskich geografów społeczno-ekonomicznych w zakresie badań miejskich obszarów funkcjonalnych (metropolitalnych) pozwala na stwierdzenie, że jest on znaczący i wykazuje trend wzrostowy, choć trzeba zwrócić uwagę na koniunkturalizm tych badań, bezpośrednio związany z natężeniem dyskursu publicznego, dotyczącego zagadnień kształtowania obszarów metropolitalnych i funkcjonalnych. Należy podkreślić szeroki zakres problematyki podejmowanej w ramach realizowanych badań podstawowych i stosowanych (kwestie teoretyczno-terminologiczne, metody badawcze, struktury, powiązania, kwestie zarządzania i planowania). Poziom aplikacji badań geograficznych jest zróżnicowany w zależności od ośrodków i zakresu współpracy z instytucjami zarządzającymi na różnych szczeblach. Geografowie mają stosunkowo niewielki wpływ na bieżące funkcjonowanie i rozwój miejskich obszarów funkcjonalnych, ale ich obecność w debacie publicznej i aktywność w kręgach eksperckich należy ocenić jako znaczące.

Miejskie obszary funkcjonalne i metropolitalne trzeba zatem uznać za ważny kierunek badań geograficznych realizowanych od początku XXI w. Ze względu na czas trwania dyskursu dotyczącego tego typu obszarów miejskich oraz spektrum zagadnień $\mathrm{w}$ ramach tej problematyki, należy w większym stopniu podjąć badania w ujęciu dynamicznym, by wykazać zmiany w czasie. Równie istotnym nurtem badawczym powinny być badania porównawcze nie tylko w skali krajowej, ale również międzynarodowej, by z jednej strony wskazać prawidłowości funkcjonowania MOF (OM), a z drugiej - specyficzne cechy wybranych struktur metropolitalnych bądź funkcjonalnych na tle innych ośrodków krajowych bądź zagranicznych. Do badań ważnych zarówno z teoretycznego, jak i poznawczego punktu widzenia, które powinny być podejmowane i rozwijane przez geografów w przyszłości, zaliczyć należy:

- badania zmian struktur i powiązań przestrzenno-funkcjonalnych (ujęcia dynamiczne);

- modelowanie rozwoju MOF (OM);

- wpływ planowania i zarządzania w skali MOF (OM) na rozwój lokalny;

- wypracowywanie koncepcji zintegrowanego planowania i zarządzania MOF (OM); 
- rozwijanie badań inter- i multidyscyplinarnych;

- badania porównawcze w skali międzynarodowej.

Ważnym zadaniem jest także lobbing, promocja badań geograficznych w celu zwiększenia ich roli w diagnozowaniu i kształtowaniu rozwoju MOF (OM) oraz udziału w tworzeniu polityk miejskich (metropolitalnych) adresowanych do tych obszarów z poziomów Unii Europejskiej, kraju, regionu i struktur lokalnych. Artykułowana w dokumentach programowych różnych szczebli zarządzania rola miejskich obszarów funkcjonalnych, jako jednego z ważnych obszarów strategicznych interwencji (OSI), upoważnia do stwierdzenia, że istotne winno być tworzenie silniejszych powiązań naukowych (akademickich) ośrodków badawczych z lokalnymi MOF. Dorobek polskich geografów daje niewątpliwie asumpt do wnioskowania o granty naukowe, udział w sieciach badawczych krajowych i międzynarodowych. Wzmożone zainteresowanie problematyką metropolitalną i zakres podejmowanych przez geografów zagadnień pozwala na przypuszczenie, że na trwale wpisze się ona $\mathrm{w}$ agendę ich badań nie tylko o zasięgu krajowym, ale i międzynarodowym. W kontekście powyższego istotny wydaje się fakt, że pomimo zakresu przeprowadzonych analiz dla lat 2000-2017, omawiany nurt badawczy w pracach geografów jest kontynuowany, ze względu na aktualność i znaczenie zagadnień metropolitalnych oraz kształtowania obszarów funkcjonalnych w Polsce. Można zatem stwierdzić, że głos geografów w dyskursie metropolitalnym pozostanie jedną z kluczowych perspektyw naukowo-badawczych i aplikacyjnych oraz ważnym odniesieniem do kierunków przeobrażeń zachodzących $\mathrm{w}$ miejskich obszarach funkcjonalnych i metropolitalnych.

\section{Literatura}

Bartosiewicz B. 2016. Obszary funkcjonalne małych i średnich miast w Polsce - koncepcja badawcza. Zeszyty Naukowe Uniwersytetu Ekonomicznego w Katowicach, 279: 234-244.

Frankowski J., Szmytkowska M. 2015. Regionalne zróżnicowanie nowych partnerstw miejskich w Polsce. Zarządzanie Publiczne, 2(30): 131-150.

Heffner K., Gibas P. 2015. Obszary funkcjonalne i ich związki z zasięgiem oddziaływania ośrodków subregionalnych (na przykładzie województwa opolskiego). Studia Miejskie, 18: 9-23.

Kaczmarek T. 2017. Miejskie obszary funkcjonalne - problemy integracji zarządzania, Studia KPZK, 174: 157-167.

Kaczmarek T. 2018. Zarządzanie obszarami metropolitalnymi - zagraniczne doświadczenia i ich polskie implikacje. Studia KPZK, 183: 273-287.

Kociuba D. 2017. Delimitacja miejskich obszarów funkcjonalnych ośrodków wojewódzkich w realizacji Zintegrowanych Inwestycji Terytorialnych w Polsce - teoria versus praktyka. Studia Regionalne i Lokalne, 3(69): 54-78.

Kozak M. 2016. Zintegrowane Inwestycje Terytorialne jako eksperyment. Studia Regionalne i Lokalne, 3(65): 50-69.

Krukowska J., Lackowska M. 2016. Metropolitalne kolory europeizacji. Instytucjonalizacja współpracy w funkcjonalnych obszarach miejskich w Polsce w świetle nowych instrumentów polityki spójności UE. Studia Regionalne i Lokalne, 1(63): 82-107.

Sokołowski D. (red.) 2016. Bibliografia prac z zakresu geografii osadnictwa i ludności za lata 1999_ 2015. Komisja Geografii Osadnictwa i Ludności PTG, Warszawa-Toruń.

Szmytkowska M. 2014. Top-down czy bottom-up? Dylematy kształtowania policentrycznych obszarów metropolitalnych na przykładzie Trójmiasta. Studia Regionalne i Lokalne, 3(57): 26-45. 
Śleszyński P. 2013. Delimitacja miejskich obszarów funkcjonalnych stolic województw. Przegląd Geograficzny, 85(2): 173-197.

Zuzańska-Żyśko E. 2016. Procesy metropolizacji. Teoria i praktyka. PWN.

\title{
Problems of functional urban (metropolitan) areas in the study of Polish socio-economic geographers
}

\begin{abstract}
An intensive political and scientific metropolitan discourse related to the development and management of metropolitan settlement structures has been underway in Poland for almost twenty years. These issues also became the subject of research by representatives of socio-economic geography. The aim of the study is to demonstrate the achievements of Polish geographers in the field of research of metropolitan areas (urban functional areas). Two basic research methods were adopted: a review of geographical papers published in 2000-2017 and a survey regarding the expert activity of geographers operating in 11 major geographical centers in Poland. The summary presents recommendations for further metropolitan research in Polish socio-economic geography.
\end{abstract}

Key words: metropolitan areas, urban functional areas, territorial management, achievements of geographical research 